\title{
The Link of Abnormal Accrual Mispricing and Value- Glamour Stock Anomaly: Evidence from the Indonesian Capital Market
}

\author{
Erni Ekawati \\ Universitas Kristen Duta Wacana, Indonesia
}

\begin{abstract}
The purpose of this study is to investigate whether abnormal accrual mispricing acknowledged in accounting literature is a manifestation of documented value-glamour anomaly in finance literature. This study proposes the traditional value-glamour proxies (sales growth, book-to-market, earningprice, cash flows-price, and size) and $\mathrm{CFO} / \mathrm{P}$ ratio (ratio of operating cash flows and stock price) to explain the mispricing of abnormal accruals.

Using a sample of 540 firm-year observations of companies listed on the Jakarta Stock Exchange (JSE) from the period of 1993 to 2003, the study finds that individually, only either the E/P or CFO/P ratio can pick up the mispricing attributed to abnormal accruals. These results can be interpreted as follows: (1) as captured by $\mathrm{E} / \mathrm{P}$ ratio, abnormal accrual mispricing is due to the market's inability to understand managers' attempts to manage reported earnings; (2) as captured by the $\mathrm{CFO} / \mathrm{P}$, the market is unable to assess the persistence of cash flows.
\end{abstract}

From a practical standpoint, this study has simplified the research agenda related to asset pricing. The result suggests that a researcher can control for the abnormal accrual mispricing and the value-glamour anomaly parsimoniously via just one variable, E/P ratio.

Abstrak: Tujuan dari penelitian ini adalah untuk menyelidiki apakah mispricing akrual tidak normal yang dikenal dalam literatur akuntansi merupakan manifestasi dari anomali saham value-glamour yang didokumentasikan dalam literatur keuangan. Penelitian ini menggunakan proksi tradisional untuk saham value-glamour (pertumbuhan penjualan, rasio nilai buku dan nilai pasar, rasio earning-price, cash flows-price, dan ukuran perusahaan) dan $\mathrm{CFO} / \mathrm{P}$ (ratio operating cashflows dan harga saham) untuk menjelaskan mispricing dari akrual tidak normal.

Dengan menggunakan 540 obseravasi (perusahaan-tahun) dari perusahaan yang terdaftar di Jakarta Stock Exchange (JSE) dari perioda 1993 sampai dengan 2003, penelitian ini menemukan bahwa hanya salah satu dari variabel $\mathrm{E} / \mathrm{P}$ atau $\mathrm{CFO} / \mathrm{P}$ yang dapat menjelaskan mispricing yang berasal dari akrual tidak normal. Hasil penelitian ini dapat diinterpretasikan sebagai berikut: (1) seperti yang dapat dijelaskan oleh variabel 
$\mathrm{E} / \mathrm{P}$, mispricing akrual tidak normal disebabkan oleh ketidakmampuan pasar dalam mengerti laporan laba yang dibuat oleh manager; (2) seperti yang dapat dijelaskan oleh variabel CFO/P, pasar tidak dapat menangkap persistensi dari cash flows.

Aplikasi praktis dari hasil penelitian ini adalah penyederhanaan agenda penelitian yang terkait dengan penilaian aset. Hasil penelitian ini merekomendasikan bahwa peneliti dapat mengontrol secara parsimoni mispricing akrual tidak normal dan anomali saham value-glamour dengan menggunakan hanya satu variabel yakni rasio $\mathrm{E} / \mathrm{P}$.

Keywords: business performance; entrepreneurial orientation; environmental uncertainty 


\section{Introduction}

Despite somewhat strong evidence that the stock market is efficient, there have been scores of studies that have documented longterm historical anomalies in the stock market. Anomalies, by their nature, represent a challenge to existing theory, and have been motivating many researchers to find plausible explanations. Hence, investigating the incidence and generalisability of anomalies will provide additional insight into the nature of this challenge to capital market efficiency. This study investigates two well known phenomena, namely value-glamour anomaly and abnormal accrual mispricing, found in finance and accounting literature, respectively, using data from the Indonesian capital market.

In finance literature, value-glamour stocks anomaly is the most publicized anomaly and is frequently touted as the best strategy for investing (Graham and Dodd 1934; De Bondt and Thaler 1985, 1987; Summers 1986; Chan 1988; Conrad and Kaul 1988; Fama and French 1988a, 1988b; Jaffe et al. 1989; Fuller et al. 1993; and Kupiec 1993). Value (glamour) stock is defined as a stock with high (low) ratios of fundamentals to price. The ratios include book-to-market $(\mathrm{B} / \mathrm{M})$, earning-to-price $(\mathrm{E} / \mathrm{P})$, and cash flowto-price $(\mathrm{C} / \mathrm{P})$. There is a large body of evidence documenting the fact that historically, value stocks are outperformed glamour stocks, and this phenomenon is robust to replication. Numerous studies employing data from non U.S. capital markets have come to similar conclusions regarding glamour and value stocks (Capaul et al. 1993; Sanders 1995; Chisolm 1991; and Keppler 1991). Similar results also document using data from the Indonesian capital market (Susiyanto 1997; Warninda and Asri 1997; Sartono 2000; and Wahyuningsih 2000).
The explanations among researchers regarding the value-glamour anomaly are divided into three different schemes. Firstly, Lakonishok et al. (1994) attribute the phenomenon to investors' error in expectations. They argue that investors overreact, in particular, investors are excessively pessimistic (optimistic) about value (glamour) stocks. Investors have lower (higher) expectations of future growth due to weak (strong) past performance of value (glamour) stocks. Secondly, another scheme of explanation is that value stocks are outperformed glamour stocks because the former is riskier (Fama and French 1992, 1993, 1996). Thirdly, methodological problems with the measurement of long-term abnormal returns create an illusion of inferior returns to glamour stocks (Fama 1998; Kothari, Sabino, and Zach 1999). This study is intended to provide insight by employing this anomaly to explain the mispricing of abnormal accruals documented in accounting literature.

Based on the accounting literature, accounting earnings can be disaggregated into two components that are accruals and cash flow from operation (CFO). Accruals and CFO should have different implication on one year ahead earnings expectations, or stated differently, they have different persistence. The accruals component should be less persistent than the CFO component. However, Sloan (1996) documents that a market fails to appreciate fully the lower persistence of the accrual component of earnings and, consequently, overprices total accruals. Using quarterly data, Collins and Hribar (2000) also find that the market overprices total accruals. Neither Sloan (1996) nor Collins and Hribar (2000) investigate whether the overpricing is due to abnormal accruals (discretionary accruals), normal accruals (non discretionary accruals), or both. Xie (2001) finds 
that the market overestimates the persistence of abnormal accruals, and consequently overprices these accruals. This result is consistent with DeFond's and Park's (2001) finding that the market overprices abnormal accruals because investors under-anticipate the future reversal of these accruals. The reported evidence of all these studies implies that the market mispricing of abnormal accruals is due to its inability to correctly assess the persistence of abnormal accruals. Pincus et al. (2005) provide international evidence about abnormal accruals mispricing employing a sample of 20 countries including Indonesia. They find that the accrual mispricing is more likely to occur in countries with a common law legal tradition where extensive use of accrual accounting is permitted and the strength of shareholder protection is weak.

In sum, one of the available explanations of both value-glamour anomaly and abnormal accruals phenomena is related to mispricing patterns. The reasons to expect that the two mispricing patterns capture the similar phenomenon are as follows: firstly, discretionary accruals as a component of total accruals are related to forecasted growth (Beaver 2002; and McNichols 2000); secondly, Decow et al. (1998) document that firms with high sales growth have large positive accruals (glamour stocks) while firms with low sales growth have negative accruals (value stocks); thirdly, both phenomena are associated with reversal of prior returns; fourthly, future abnormal returns related to value-glamour anomalies are concentrated surrounding subsequent earnings announcement (LaPorta et al. 1997; Sloan 1996).

Desai et al. (2004) find a new variable, namely $C F O / P$, operating cash flows mea- sured as earnings adjusted for depreciation and working capital accruals scaled by price, captures mispricing attributed to the traditional value-glamour proxies (past sales growth, $\mathrm{B} / \mathrm{M}, \mathrm{E} / \mathrm{P}$, and $\mathrm{C} / \mathrm{P})$ and accruals. This finding suggests that the $C F O / P$ variable can be considered an expanded valueglamour proxy. The $C F O / P$ in Desai's et al. (2004) study can pick up the accrual mispricing. This result is also consistent with Beavers's (2002) conjecture that the accruals anomaly is the glamour stock phenomenon in disguise.

The purpose of this study is to provide empirical evidence from the Indonesian capital market regarding the value-growth anomaly previously described, whether the anomaly is a manifestation of the mispricing of abnormal accruals. There has been no study investigating whether the accrual phenomenon is a manifestation of the valueglamour stocks anomaly in the Indonesian capital market. This study is important because, firstly, it contributes an important piece to the puzzle surrounding the two related anomalies; secondly, it discovers a variable that subsumes abnormal returns related to both accruals and the traditional value-glamour proxies as found in Desai et al. (2004); thirdly, it facilitates a further investigation about what exactly the market misprices - accounting manipulation through accruals, or cash flow information, or expectations about future growth. To find out why the accruals and value-growth stock anomalies occur will contribute to the literature on the connection between institutional and corporate governance structures and the uses of accounting information in equity market. 


\section{Related Studies and Hypotheses Development}

\section{Anomalies and Market Efficiency}

Anomalies are empirical results that seem inconsistent with maintained theories of asset pricing behavior. They indicate either market inefficiency (profit opportunities) or inadequacies in the underlying asset-pricing model. Finance and accounting literature pays a great deal of attention to the efficiency of capital markets. Research in this area most commonly examines market anomalies, which are defined simply as predictable abnormal returns (Ball 1992).

At the fundamental level, anomalies can only be defined relative to a model of normal return behavior. Fama (1970) notes this fact early on, pointing out that tests of market efficiency also jointly test a maintained hypothesis about equilibrium expected returns. Thus, whenever someone concludes that a finding seems to indicate market inefficiency, it may also be evidence that the underlying asset pricing model is inadequate.

However, it is also important to consider the economic relevance of a presumed anomaly that will be addressed in this study. Jensen (1978) stressed the importance of trading profitability in assessing market efficiency. In particular, if anomalous return behavior is not definitive enough for an efficient trader to make money trading on it, then it is not economically significant. This definition of market efficiency directly reflects the practical relevance of academic research into return behavior.

\section{Value-Glamour Anomaly}

The value-glamour phenomenon refers to the empirical regularity that value socks are outperformed glamour stocks. Value (glamour) stocks are identified with the low (high) past sales growth, high (low) B/M, E/ $\mathrm{P}$, and $\mathrm{C} / \mathrm{P}$. A trading strategy employing these ratios, commonly called a contrarian strategy, results in economically significant abnormal return.

In an influential paper, Lakonishok, Shleifer, and Vishny (1994) atribute the superior (inferior) performance of value (glamour) stocks to errors in expectations on the part of investors about future growth prospects of these firms. Lakonishok et al.(1994) posit and find that value stocks are underpriced because investors appear to extrapolate poor past growth rates into the future and, hence, are pessimistic about such stocks. On the other hand, investors are overly optimistic about glamour stocks and have higher expectations of future growth because these firms have strong earnings and growth in the past. As growth rates mean-revert in the future, investors are positively (negatively) surprised by the performance of value (glamour) stocks. Numerous studies of foreign stock markets have come to similar conclusions regarding glamour-value stocks anomaly (Capaul et al. 1993; Sanders 1995; Chisolm 1991; and Keppler 1991). Similar results are also documented using data from the Indonesian capital market (Susiyanto 1997; Warnin and Asri 1997; Sartono 2000; Wahyuningsih 2000).

Accordingly, the hypothesis related to value-glamour stocks can be stated as follows: 
$H_{1}$ : Performance of value stocks characterized by the firms with low past sales growth, high B/ $M$, high $E / P$, high $C / P$, high $C F O / P$, and big size are outperformed that of glamour stocks characterized by the firms with high past sales growth, low $B / M$, low $E / P$, low $C / P$, low $\mathrm{CFO} / \mathrm{P}$, and small size.

\section{Abnormal Accrual Mispricing}

Sloan (1996) demonstrates that a trading strategy based on long (short) position in stocks that are in the lowest (highest) decile of accruals generate significant abnormal returns in the following year. Sloan's results are anomalous to capital market efficiency, and the anomaly appears to stem from the inability of investors to recognize differences in persistence between the accruals and operating cash flow components of earnings. That is, investors implicitly assign a higher weight to accruals in pricing stocks ignoring that accruals mean-revert more rapidly than operating cash flows.

Subramanyam (1996) demonstrates that the overpricing of total accruals that Sloan (1996) documented is due largely to abnormal accruals. Hong Xie (2001), in his study also finds the mispricing of abnormal accruals. The results are robust to five alternative measures of abnormal accruals, and still hold when he estimates abnormal accruals after controlling for major unusual but largely nondiscretionary accruals. This finding is consistent with the notion that the market overprices the portion of abnormal accruals stemming from managerial discretion.

A number of studies have shown that the accrual phenomenon is robust across various samples of U.S. firms (Collins and Hribar 2000; Bradshaw et al. 2001; Zach 2002). Similarly, Pincus et al. (2005) provide international evidence about the accruals phe- nomenon employing sample of 20 countries including Indonesia.

Accordingly, the hypothesis related to abnormal accrual mispricing in which earnings expectations in stock prices overweight the lower persistence of the accrual component of earnings, can be stated as follows:

$\mathrm{H}_{2}$ : Performance of stocks characterized by the firms with low abnormal accruals are outperformed by that of stocks characterized by the firms with high abnormal accruals.

\section{The Use of Value-Glamour Proxies to Explain the Abnormal Accrual Mispricing}

As described previously, the anomaly of value-glamour stocks occurs because investors extrapolate past growth in sales, earnings, and cash flow, and realize subsequently, mostly at the time of future earnings announcements (La Porta et al. 1997), that such growth is not sustainable due to the mean reverting of growth rates. Similarly, the accrual phenomenon occurs because investors extrapolate past earnings into the future and are surprised when earnings announced subsequently are lower or higher than expected due to accruals reversals. Thus, both phenomena relate to errors in expectations about future fundamentals, in turn, there must be a certain proxy that can link the two corresponding phenomena.

This study examines whether the abnormal accrual phenomenon is an aspect of the value-glamour anomaly documented worldwide in the finance literature (Fama and French 1998). Desai et al. (2004) show that the accrual phenomenon and the valuegrowth anomaly are captured by abnormal returns to a new variable, $\mathrm{CFO} / \mathrm{P}$, in the USA. 
Accordingly, this study hypothesize as follows:

\section{$H_{3}$ : Abnormal accrual mispricing phenomenon is subsumed in the value-glamour anomaly.}

\section{Methodology}

\section{Data}

Financial data and capital market data are collected for all firms listed on the Jakarta Stock Exchange from financial report database of Jakarta Stock Exchange and PDPM database of Accounting Development Center of Universitas Gadjah Mada. The period of coverage is 1990-2004.

All firms with available data are included in the sample. Following Lakonishok et al. (1994) financial firms, such as banks and insurance companies, are excluded because of peculiarities in the accruals for such firms. Firms with negative book values and earnings are also eliminated because $B / M$ and $E$ / $P$ for such firms do not lend themselves to intuitive interpretation as a growth proxy.

\section{Variable Definitions}

The following are variables used to proxy value-glamour stocks:

- $S G$ (past sales growth) measured as the average of annual growth in sales over the previous three years.

- $B / M$ measured as the ratio of the fiscal year-end-book value of equity to the market value of equity.

- $E / P$ measured as earnings after tax scaled by the market value of equity.

- $C / P$ measured as earnings after tax plus depreciation scaled by market value of equity.
The following are variables used to measure total accruals (TACC):

$$
\begin{aligned}
\text { TACC }= & (\text { DCA-DCash })-(\text { DCL-DSTD })- \\
& \text { Dep }
\end{aligned}
$$

where:

$$
\begin{aligned}
& \text { Working Capital Accruals = } \\
& \text { (DCA-DCash)-( DCL-DSTD) }
\end{aligned}
$$

- DCA: change in current assets

- DCash: change in cash/cash equivalent

- DCL: change in current liabilities

- DSTD: change in short term debt included in current liabilities

- Dep: depreciation

$\mathrm{CFO} / \mathrm{P}$ is measured as cash flow from operation scaled by the market value of equity, where:

$$
\begin{aligned}
\mathrm{CFO}= & \text { Earnings }+ \text { Depreciation }- \\
& \text { Working Capital Accruals }
\end{aligned}
$$

The analysis focuses on comparing the abnormal returns due to accruals and the traditional value-glamour proxies. The abnormal returns are computed after forming portfolios based on the four traditional variables of value-glamour stocks and one variable of accruals. Each firm is ranked and assigned into quintiles based on each variable used to identify value-glamour stocks and accruals. Annual raw buy-and-hold returns and size-adjusted returns for each firm are calculated for each of the one year after portfolios are formed. At the end of each year, the portfolio is rebalanced. The annual size-adjusted return for a firm is the difference between the annual buy-and-hold return for the firm 
and the average annual buy-and-hold return of the size quintiles portfolio to which the firm belongs.

The Jones model is used to estimate normal accruals and abnormal accruals:

$$
\begin{aligned}
\text { TACC }_{\mathrm{t}} / \mathrm{TA}_{\mathrm{t}-1}= & \alpha_{1}\left[1 / \mathrm{TA}_{\mathrm{t}-1}\right]+ \\
& \alpha_{2}\left[\Delta \mathrm{REV}_{\mathrm{t}} / \mathrm{TA}_{\mathrm{t}-1}\right]+ \\
& \alpha_{3}\left[\Delta \mathrm{PPE}_{\mathrm{t}} / \mathrm{TA}_{\mathrm{t}-1}\right]+\mathrm{e}_{\mathrm{t}}
\end{aligned}
$$

where:

$\mathrm{TA}_{\mathrm{t}-1}$ : beginning of year total assets

DREV $_{t}$ : change in revenues

PPE: gross property, plant, and equipment

$\mathrm{e}_{\mathrm{t}}$ : abnormal accruals (ABACC), while the predicted values are normal accruals (NACC)

\section{Statistical Model and Hypothesis Testing}

To facilitate the test of Hypothesis 1, 2 , and 3 the following tests are conducted:

\section{Basic hedge test}

A basic hedge test is used to observe mean differences of portfolios' returns in the extreme (the lowest and the highest) quintile. A simple T-test procedure is used to measure the significance of the difference. $H_{1}$ is supported when:

- Portfolios in the lowest quintile of sales growth should be significantly outperformed by those of in the highest quintile.

- Portfolios in the highest quintile of $B / M$, $E / P, C / P, C F O / P$, SIZE should be significantly outperformed by those of in the lowest quintile.
H2 is supported when:

Portfolios in the lowest quintile of abnormal accruals (ABACC) should be significantly outperformed those in the highest quintile.

\section{Regression approach}

The regression approach used to test $H_{1}$, $H_{2}$, and $H_{3}$ follows Fama's and MacBeth's (1973) model. Portfolios are formed using the same procedure described above to determine quintile ranks. The scaled rank for each variable is computed for each year by annually ranking the corresponding variable value into quintile (0 to 4$)$ and dividing the quintile by 4 such that each observation related to the corresponding variable takes a value ranging between 0 to 1 .

The regression models are stated as follows:

Model I:

$$
\begin{aligned}
\mathrm{SAR}_{1}= & \alpha_{1}+\alpha_{2} \mathrm{SG}^{q u \text { int }}+\alpha_{3} \mathrm{BM}^{q u \text { int }}+ \\
& \alpha_{4} \mathrm{EP}^{q u \text { int }}+\alpha_{3} \mathrm{CP}^{q u \text { int }}+ \\
& \alpha_{6} \mathrm{CFOP}^{q u \text { int }}+\alpha_{7} \mathrm{SIZE}^{q u \text { int }}+ \\
& \mathrm{e}_{t+1}
\end{aligned}
$$

Model II:

$$
\mathrm{SAR}_{1}=\beta_{1}+\beta_{2} \mathrm{ABACC}+\beta_{3} \mathrm{NACC}+\mathrm{e}
$$

Model III:

$$
\begin{aligned}
\mathrm{SAR}_{1}= & \beta_{1}+\beta_{2} \mathrm{ABACC}+\beta_{3} \mathrm{NACC}+ \\
& \alpha_{2} \mathrm{SG}^{q u \text { int }}+\alpha_{3} \mathrm{BM}^{q u \text { int }}+ \\
& \alpha_{4} \mathrm{EP}^{q u \text { int }}+\alpha_{3} \mathrm{CP}^{q u \text { int }}+ \\
& \alpha_{6} \mathrm{CFOP}^{q u \text { int }}+\alpha_{7} \mathrm{SIZE}^{q u \text { int }}+\mathrm{e}_{t+1}
\end{aligned}
$$


where $S A R_{t+1}$ is annual size-adjusted abnormal return of each firm, one year after portfolios formation. $S G^{\text {quint }}, B M^{\text {quint }}, E P^{\text {quint }}, C P^{\text {quint }}$, $\mathrm{CFO}^{\text {quint }}$, and SIZE ${ }^{\text {quint }}$ relate to scaled-quintile ranks (ranging from 0 to 1 ) of accruals, past sales growth, book-to-market, earning-toprice, cash flows to price, operating cash flows to price, and size portfolios, respectively. The coefficients on $S G^{\text {quint }}, B M^{\text {quint }}$, $E P^{\text {quint }}, C P^{\text {quint }}, C F O^{\text {quint }}$, and SIZE $E^{\text {quint }}$ represents adjusted abnormal return to a zero-investment portfolio optimally formed to exploit the information in the corresponding variable.

To test the $H_{1}$, the expected signs of coefficient of each variable in Model I are as follows:

- $S G^{\text {quint }}$ is negative and significant, following the effect of value-glamour anomaly.

- $B M^{\text {quint }}$ is positive and significant, following the effect of value-glamour anomaly.

- EPquint is positive and significant, following the effect of value-glamour anomaly.
- $C P^{\text {quint }}$ is positive and significant, following the effect of value-glamour anomaly.

- SIZEquint is positive and significant

To test the $H_{2}$, the expected signs of coefficient of each variable in Model II are as follows:

- $A B A C C$ is negative and significant, following the effect of mispricing abnormal accrual.

- NACC is not significant.

To test the $H_{3}$, the expected sign of ABACC coefficient is not significant after controlling with value-glamour proxies, as shown in Model III.

\section{Empirical Analysis}

\section{Summary Statistics of the Data}

Table 1 provides a summary statistics of variables of interest across firm-year observations. There are 540 firms within an 11

Table 1. Summary Statistics

Panel A: Descriptive Statistics

\begin{tabular}{lcccc}
\hline Variable & Mean & $\begin{array}{c}\text { Standard } \\
\text { Deviation }\end{array}$ & Minimum & Maximum \\
\hline SG & 0.30 & 0.43 & -0.44 & 6.70 \\
BM & 1.11 & 1.01 & 0 & 9.21 \\
EP & 0.19 & 0.60 & 0 & 13.04 \\
CP & 0.78 & 1.30 & 0 & 17.47 \\
CFOP & 0.34 & 1.23 & -4.96 & 8.21 \\
LNSIZE & 12.34 & 1.79 & 7.51 & 17.4 \\
TACC/TA & -0.15 & 2.23 & -13.76 & 47.59 \\
ABACC/ TA & -0.24 & 0.88 & -6.92 & 5.17 \\
NACC/ TA ${ }_{\mathrm{t}-1}$ & 0.09 & 2.03 & -11.61 & 42.42 \\
R1 & -0.10 & 0.52 & -1.0 & 2.33 \\
SAR1 & -0.03 & 0.40 & -1.23 & 1.22 \\
N= 540 & & & & \\
\hline
\end{tabular}




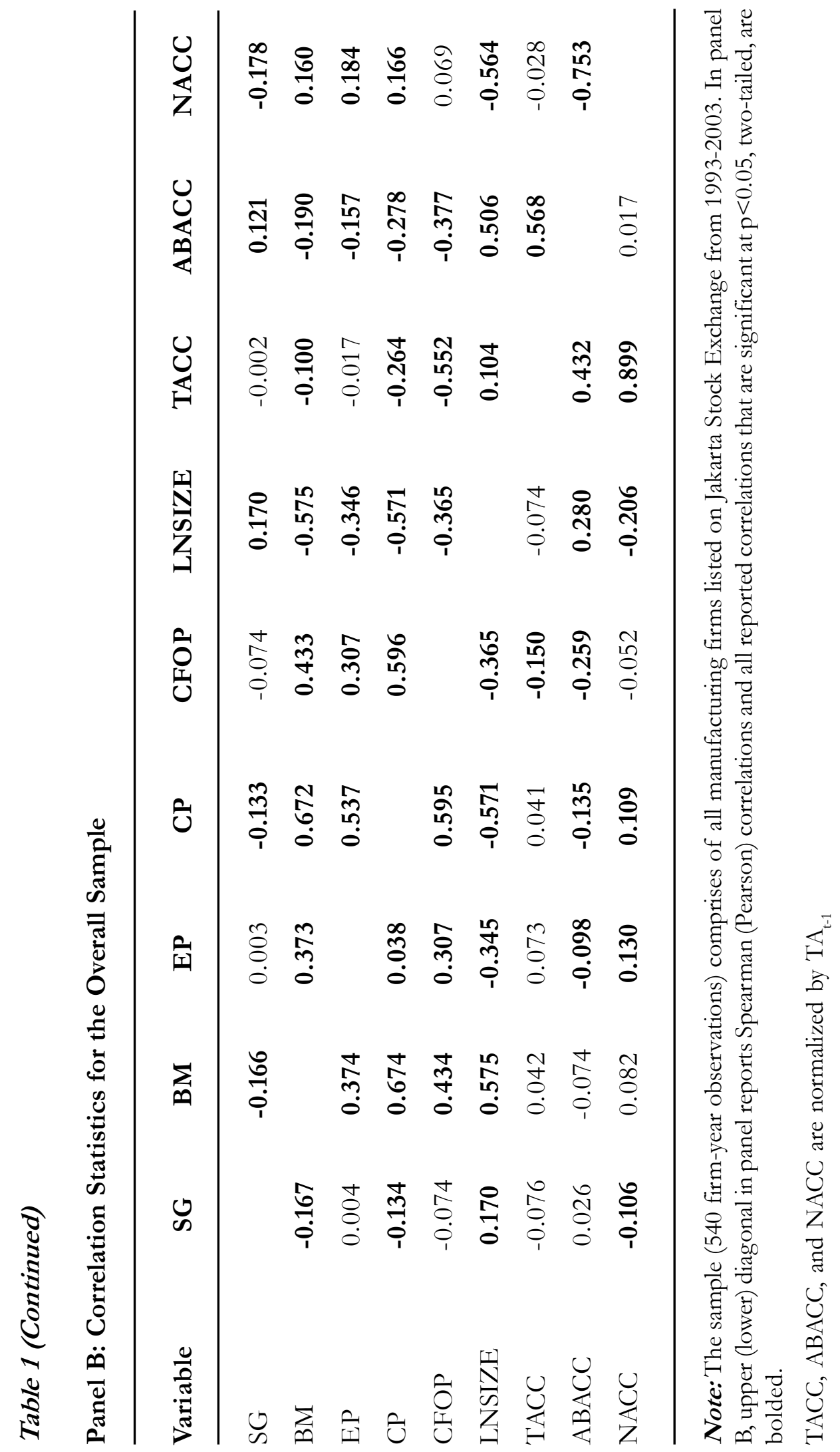


year period (1993-2003). Panel A of Table 1 shows the descriptive statistics of each variable. The means of accruals (TACC/TA ${ }_{\mathrm{t}-1}$ and $\left.\mathrm{ABACC} / \mathrm{TA}_{\mathrm{t}-1}\right)$ are negative $(-0.15$ and 0.24 , respectively) across firm-year observations suggesting that depreciation dominates other working capital accruals.

The mean, minimum, and maximum of $B / M$ and $E / P$ ratios are positive because some firm-year observations are excluded, especially during the crisis period (19982000), due to negative book values and earnings, respectively. Before excluding the negative book values and earnings, there are 735 firm-year observations. After excluding the negative ones, there are 565 firm-year observations. This study ends up with 540 firmyear observations after removing outliers.

The minimum and maximum of all value-glamour proxies are more than three times the standard deviations. However, the relative wide range in value-glamour variables does not affect the result due to the use of quintiles rank as opposed to actual values.

The correlation matrix in Panel B shows the Spearman and Pearson correlations among the variables of interest. Using the Spearman correlation matrix, $\mathrm{T} A C C / \mathrm{T} A_{t-1}$ has a high negative correlation of -0.552 with $C F O / P$ ratio. $C / P$ and $C F O / P$ ratios also have a high positive correlation of 0.596 . This correlation is in line with the way the ratios are computed. The $C / P$ ratio has a high positive correlation with the $B / M$ and $E / P$ ratios, while $L N S I Z E$ has a negative correlation with $B / M$ and $C / P$ ratios. The Pearson correlation matrix shows similar results.

\section{Results of Basic Hedge Tests}

The basic hedge test reports returns to an unconditional value-glamour stocks and accruals strategy. Employing basic hedge strategy means taking a long position on portfolios that will generate higher future returns $\left(\mathrm{RET}_{\mathrm{t}+1}\right)$, and a short position on portfolios that will generate a lower future returns. This strategy will result in a positive future returns. The portfolios in the extreme quintiles (quintile 1 and 5) meet this requirement. Table 2 reports raw returns $\left(\mathrm{RET}_{1}\right)$ and size adjusted returns $\left(\mathrm{SAR}_{1}\right)$ for each of the following year after portfolio formation. The returns are buyand-hold returns for 12 months after portfolio formation (month +1 to +12 ).

Panels A to F of Table 2 replicate the strategy using the value-glamour proxies, such as $S G, B / M, E / P, C / F, C F O / P$, and LNSIZE. Value (growth) stocks are identified by firms in the lowest (highest) quintile of $B / M, E / P$, $C / P, C F O / P$, and LNSIZE. Value (glamour) stocks generate higher (lower) returns (R1) and size-adjusted returns $\left(\mathrm{SAR}_{1}\right)$. $S G$ strategy has a reversed direction. Except for LNSIZE strategy, the directions of one-year future returns and size-adjusted returns of $S G$, $B / M, E / P, C / P$, and $C F O / P$ strategies, as shown in column 7 of Table 2 , are consistent with the usual value-glamour strategy. However, the magnitudes of the return differences are not statistically significant. The reason is due to short periods of year observations which is only 11 years data available to form portfolios.

Panel $G$ to I of Table 2 reports the one year return and size adjusted return to the accrual strategy. Only strategy using normal accruals (NACC/TA ${ }_{t-1}$ ) can earn positive returns and abnormal returns. The lowest accruals quintile earns a return of -5.4 percent in the post formation year while top quintile of accruals earns an average return of -15.6 percent. Using size adjusted returns, the firms in the bottom quintile of accruals earn a return of 0.9 percent and those in the top quintile earn an abnormal return of -9.8 per- 
cent. Consistent with Sloan (1996), returns associated with the extreme low-accruals portfolios are higher while those related to the extreme high accruals portfolio are lower. Even though the directions of the results are consistent but they are not statistically significant. As in value-glamour strategy, the same reason lends support to these explanations.
The results of the basic hedge test are only able to confirm the directions of the returns of value-glamour and accruals strategies stated in $H_{1}$ and $H_{2}$. However, the magnitudes of the return differences are not statistically supported.

Table 2. Returns and Size Adjusted Returns to Various Portfolios

Panel A: Sales Growth (SG) Portfolio

\begin{tabular}{|c|c|c|c|c|c|c|c|}
\hline & Value & & Quintile & & Glamour & & \\
\hline & 1 & 2 & 3 & 4 & 5 & $1-5$ & P-value \\
\hline SG & 0.023 & 0.159 & 0.244 & 0.329 & 0.725 & -0.702 & 0.000 \\
\hline $\mathrm{R} 1$ & -0.138 & -0.080 & -0.070 & -0.080 & -0.123 & -0.015 & 1.000 \\
\hline SAR1 & -0.956 & -0.004 & -0.017 & -0.009 & -0.041 & -0.054 & 0.863 \\
\hline
\end{tabular}

\section{Panel B: Book-to-Market Ratio (BM) Portfolio}

\begin{tabular}{lccccccc}
\hline & Value & \multicolumn{3}{c}{ Quintile } & \multicolumn{3}{c}{ Glamour } \\
\cline { 2 - 6 } & $\mathbf{1}$ & $\mathbf{2}$ & $\mathbf{3}$ & $\mathbf{4}$ & $\mathbf{5}$ & $\mathbf{1 - 5}$ & P-value \\
\hline BM & 0.263 & 0.586 & 0.911 & 1.397 & 2.328 & 2.065 & 0.000 \\
R1 & -0.217 & -0.109 & -0.085 & -0.021 & -0.066 & 0.110 & 0.271 \\
SAR1 & -0.130 & -0.030 & -0.006 & 0.016 & -0.020 & 0.152 & 0.197 \\
\hline
\end{tabular}

\section{Panel C: Earning-to-Price Ratio (EP) Portfolio}

\begin{tabular}{|c|c|c|c|c|c|c|c|}
\hline & & Value & Quintile & Glamour & & & \\
\hline & 1 & 2 & 3 & 4 & 5 & $1-5$ & P-value \\
\hline EP & 0.030 & 0.071 & 0.111 & 0.183 & 0.522 & 0.492 & 0.000 \\
\hline $\mathrm{R} 1$ & -0.241 & -0.164 & -0.107 & -0.022 & 0.039 & 0.280 & 0.001 \\
\hline SAR1 & -0.197 & -0.093 & -0.013 & 0.044 & 0.090 & 0.287 & 0.000 \\
\hline
\end{tabular}


Gadjah Mada International Journal of Business - January-April, Vol. 14,No. 1, 2012

Table 2 (Continued)

Panel D: Cashflow-to-Price Ratio (CP) Portfolio

\begin{tabular}{|c|c|c|c|c|c|c|c|}
\hline & Value & & Quintile & & Glamour & & \\
\hline & 1 & 2 & 3 & 4 & 5 & $1-5$ & $\mathbf{P}$-value \\
\hline $\mathrm{CP}$ & 0.118 & 0.278 & 0.484 & 0.846 & 2.077 & 1.960 & 0.000 \\
\hline $\mathrm{R} 1$ & -0.198 & -0.158 & -0.068 & -0.053 & -0.020 & 0.178 & 0.085 \\
\hline SAR1 & -0.131 & -0.071 & 0.040 & -0.022 & 0.014 & 0.145 & 0.066 \\
\hline
\end{tabular}

Panel E: Cashflow of Operation-to-Price Ratio (CFOP) Portfolio

\begin{tabular}{|c|c|c|c|c|c|c|c|}
\hline & Value & & Quintile & & Glamour & & \\
\hline & 1 & 2 & 3 & 4 & 5 & $1-5$ & P-value \\
\hline CFOP & -0.626 & -0.005 & 0.192 & 0.513 & 1.593 & 2.219 & 0.000 \\
\hline R1 & -0.133 & -0.157 & -0.095 & -0.061 & -0.038 & 0.095 & 0.666 \\
\hline SAR1 & -0.098 & -0.089 & -0.018 & 0.003 & 0.033 & 0.132 & 0.121 \\
\hline
\end{tabular}

Panel F: Size (LNSIZE) Portfolio

\begin{tabular}{|c|c|c|c|c|c|c|c|}
\hline & Value & & Quintile & & Glamour & & \\
\hline & 1 & 2 & 3 & 4 & 5 & $1-5$ & P-value \\
\hline LNSIZE & 10.102 & 11.237 & 12.148 & 13.032 & 15.007 & 4.905 & 0.000 \\
\hline R1 & 0.040 & -0.065 & -0.135 & -0.206 & -0.118 & -0.157 & 0.166 \\
\hline SAR1 & -0.006 & 0.004 & -0.047 & -0.070 & -0.045 & -0.038 & 0.959 \\
\hline \multicolumn{8}{|c|}{ Panel G: Total Accruals (TACC/ TA t-1 ) Portfolio } \\
\hline & \multicolumn{2}{|l|}{ Value } & \multicolumn{2}{|l|}{ Quintile } & Glamour & \multirow[b]{2}{*}{$1-5$} & \multirow[b]{2}{*}{ P-value } \\
\hline & 1 & 2 & 3 & 4 & 5 & & \\
\hline TACC & -0.962 & -0.260 & -0.151 & -0.061 & 0.624 & -1.586 & 0.000 \\
\hline $\mathrm{R} 1$ & -0.081 & -0.065 & -0.140 & -0.048 & -0.156 & 0.074 & 0.833 \\
\hline SAR1 & -0.023 & -0.008 & -0.088 & 0.008 & -0.054 & -0.014 & 0.999 \\
\hline
\end{tabular}


Table 2 (Continued)

Panel H: Abnormal Accruals (ABACC/ TA ${ }_{t-1}$ ) Portfolio

\begin{tabular}{lccccccc}
\hline & Value & \multicolumn{3}{c}{ Quintile } & \multicolumn{3}{c}{ Glamour } \\
\cline { 2 - 7 } & $\mathbf{1}$ & $\mathbf{2}$ & $\mathbf{3}$ & $\mathbf{4}$ & $\mathbf{5}$ & $\mathbf{1 - 5}$ & P-value \\
\hline ABACC & -0.330 & -0.033 & -0.211 & -0.241 & -0.373 & 0.0433 & 0.996 \\
R1 & -0.096 & -0.142 & -0.023 & -0.122 & -0.106 & 0.010 & 1.000 \\
SAR1 & -0.067 & -0.047 & 0.027 & -0.079 & 0.003 & -0.069 & 0.722 \\
\hline
\end{tabular}

Panel I: Normal Accruals (NACC/ TA t-1 $_{\text {) Portfolio }}$

\begin{tabular}{lccccccc}
\hline & Value & \multicolumn{3}{c}{ Quintile } & \multicolumn{3}{c}{ Glamour } \\
\cline { 2 - 6 } & $\mathbf{1}$ & $\mathbf{2}$ & $\mathbf{3}$ & $\mathbf{4}$ & $\mathbf{5}$ & $\mathbf{1 - 5}$ & P-value \\
\hline NACC & 0.102 & 0.354 & 0.033 & 0.049 & -0.092 & 0.194 & 0.955 \\
R1 & -0.054 & -0.075 & -0.076 & -0.125 & -0.156 & 0.102 & 0.588 \\
SAR1 & 0.009 & 0.001 & -0.039 & -0.033 & -0.098 & 0.107 & 0.287 \\
& & & & & & & \\
\hline
\end{tabular}

\section{Regression Results}

Table 3 reports the regression coefficient of each variable of value-glamour proxies. The results indicate that, individually, each value glamour proxy, except for $S G$ and LNSIZE, can explain the variation on oneyear future abnormal returns (SAR1) across firms. Putting all value-glamour proxies in one regression model, the study shows that $E / P$ ratio is the only variable that can explain the variation of one-year future abnormal return.

Individually, $E / P, C / P, C F O / P$ ratios have a strong positive relation with $S A R 1$, the relations are statistically significant at 1 percent alpha level with the regression coefficients of $0.284,0.133$, and 0.142 , respectively. $B / M$ has a positive relation with $S A R 1$, and the relation is statistically significant at
5 percent alpha level with regression coefficient of 0.106 . The multiple regression employing all value-glamour proxies results in just one variable, $E / P$, that has a positive relation and significance at the 1 percent alpha level with $S A R 1$ with regression coefficient of 0.300 . This result indicates that $E / P$ ratio is able to pick up the value-glamour proxies represented by $S G, B / M, C / P, C F O / P$, and $L N S I Z E$ ratios in the regression model. Thus, as stated in $\mathrm{H} 1$ that performance of value stocks characterized by the firms with high $B / M$, high $E / P$, high $C / P$, high $C F O / P$ are outperformed that of glamour stocks characterized by the firms with low $B / M$, low $E$ / $P$, low $C / P$, and low $C F O / P$, respectively, is supported. Additionally, $E / P$ ratio subsumes the anomaly represented by the other valueglamour proxies. 
Gadjah Mada International Journal of Business -January-April, Vol. 14,No. 1, 2012

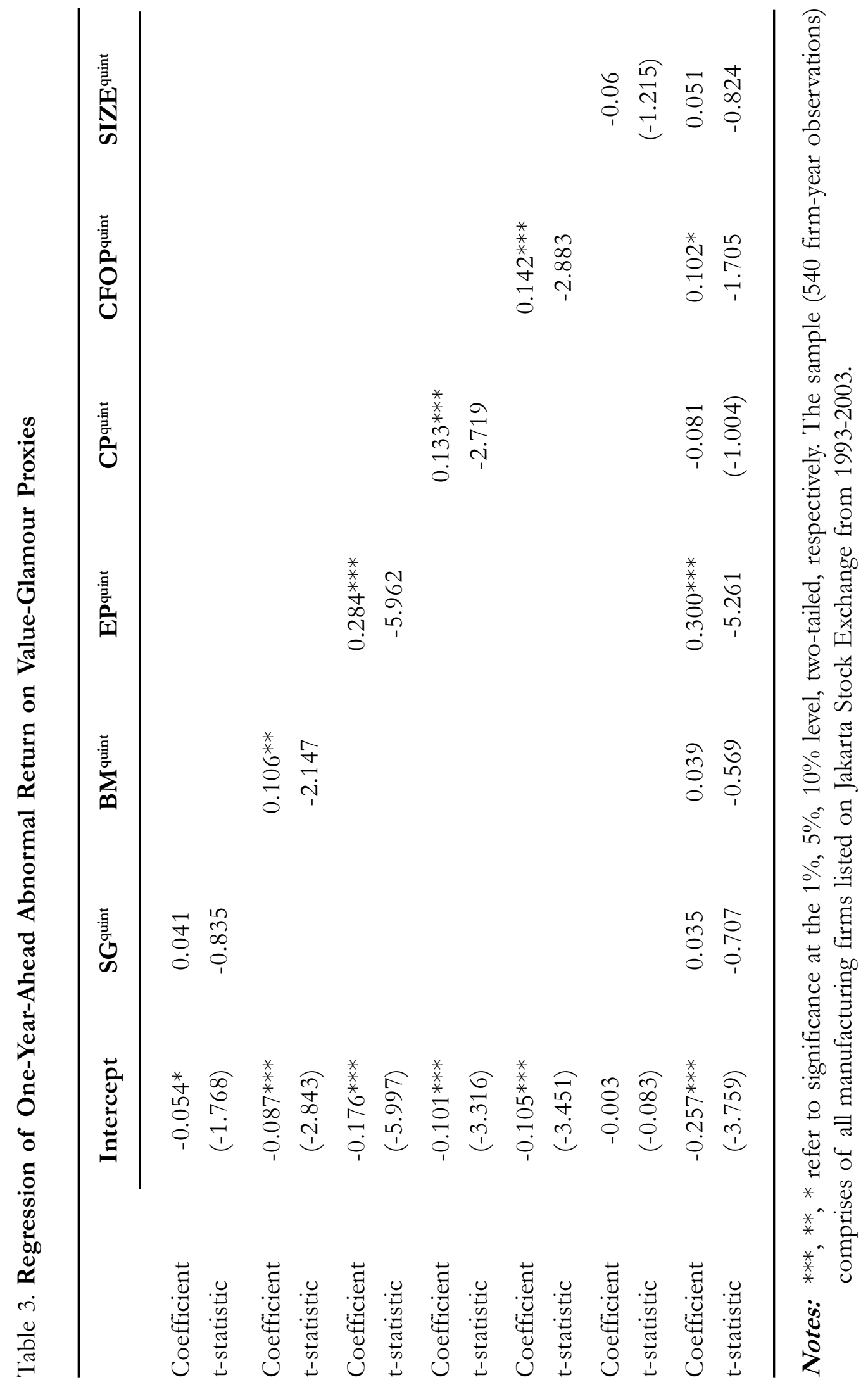


Table 4 shows that the regression coefficient of total accruals, abnormal accrual, and normal accrual (TACC/TAt-1, ABACC/ TAt-1, and NACC/TAt-1) on one-year future abnormal return (SAR1). Only abnormal accrual variable has a negative and significant relation with SAR1. The regression coefficient is -0.039 and significance at 5 percent alpha level. This result supports the $\mathrm{H} 2$ that the higher (lower) the accruals the lower (the higher) the one-year future abnormal returns. Thus, this study presents empirical evidence of abnormal accrual mispricing.

Table 5 shows the regression of oneyear abnormal return $\left(\mathrm{SAR}_{1}\right)$ on value glamour proxies and accruals. The results indicate that, individually, value glamour proxies represented by $E / P$ and $C F O / P$ only that can pick up the abnormal accrual mispricing on one-year future returns across firms. Thus, abnormal accrual mispricing phenomenon is subsumed in the value-glamour anomaly (that can be represented by $\mathrm{E} / \mathrm{P}$ and $\mathrm{CFO} / \mathrm{P}$ ) as stated in $\mathrm{H} 3$ is supported.

Putting all the abnormal accrual, normal accrual, and value-glamour proxies in one regression model, the study shows that $E / P$ ratio is the only variable that can explain the variation of one-year future return. The regression coefficient of $E / P$ ratio is 0.294 and statistically significant at the alpha level of 1 percent. This result indicates that $E / P$ ratio is not only able to pick up the abnormal accrual mispricing, but also value-glamour proxies represented by $S G, B / M, C / P, C F O / P$ ratios, and LNSIZE in the regression model. Thus, this study presents a simple variable of $E / P$ ratio that can control the accrual

Table 4. Regression of One-Year-Ahead Abnormal Return on Accruals

\begin{tabular}{|c|c|c|c|c|}
\hline & Intercept & TACC $/ \mathbf{T A}_{\mathrm{t}-1}$ & ABACC/ $\mathbf{T A}_{\mathrm{t}-1}$ & NACC / TA ${ }_{t-1}$ \\
\hline Coefficient & $-0.033^{*}$ & 0.001 & & \\
\hline t-statistic & $(-1.874)$ & -0.105 & & \\
\hline Coefficient & $-0.042^{* *}$ & & $-0.039 * *$ & \\
\hline t-statistic & $(-2.344)$ & & $(-1.984)$ & \\
\hline Coefficient & $-0.043 * *$ & & & 0.007 \\
\hline t-statistic & $(-1.923)$ & & & -0.886 \\
\hline Coefficient & $-0.043^{* *}$ & & $-0.039 * *$ & 0.008 \\
\hline t-statistic & $(-2.384)$ & & $(-1.999)$ & -0.922 \\
\hline
\end{tabular}

Notes: ${ }^{* * *},{ }^{* *}, *$ refer to significance at the $1 \%, 5 \%, 10 \%$ level, two-tailed, respectively. The sample (540 firm-year observations) comprises of all manufacturing firms listed on Jakarta Stock Exchange from 1993-2003. 
Gadjah Mada International Journal of Business -January-April, Vol. 14,No. 1, 2012

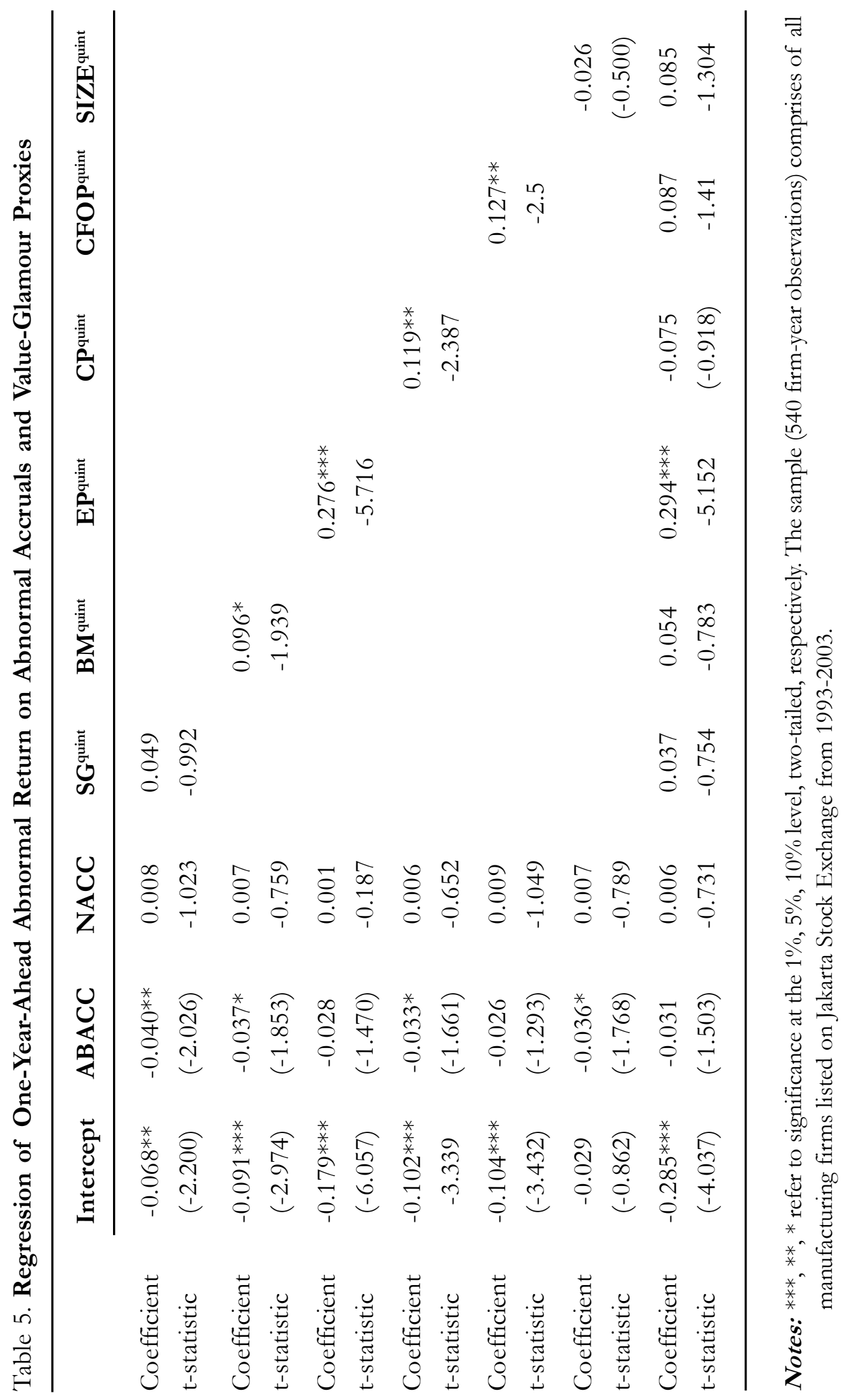


mispricing and value-glamour anomaly in Indonesia stock market. This result is similar to Desai's at al. (2004) study that presents a new variable of $C F O / P$ to control the two phenomena in the US stock market.

\section{Conclusions}

This study investigates whether accounting accrual anomaly acknowledged in accounting literature is a manifestation of documented value-glamour anomaly in finance literature. To accomplish this purpose, the study firstly confirms the existence of value-glamour and accruals anomalies using a sample of 540 firm-year observations of companies listed in Jakarta Stock Exchange (JSE) from the periods of 1993 to 2003.

The results of this study show that, individually, $B / M, E / P, C / P$, and $C F O / P$ ratios can be used as value-glamour proxies in the Indonesian capital market. Related to accrual phenomena, only abnormal accrual produces the mispricing phenomenon. Individually, only either the $E / P$ or $C F O / P$ ratio can pick up the mispricing attributed to abnormal accruals. These results can be interpreted as follows: (1) as captured by the E/P ratio, abnormal accrual mispricing is due to the market's inability to understand managers' attempts to manage reported earnings; (2) as captured by the $C F O / P$, the market is unable to assess the persistence of cash flows. From a practical standpoint, this study has simplified the research agenda related to asset pricing. The result suggests that a researcher can control for the abnormal accrual mispricing and the value-glamour anomaly parsimoniously via just one variable, the $E$ / $P$ ratio. It follows the rationale that investors in the Indonesian capital market use the $E / P$ ratio as the main valuation method to determine the buy-hold investment strategy in capital market.

The study does not investigate further the underlying cause of the $E / P$ anomaly. It is possible that the underlying causes of the two phenomena, namely abnormal accrual mispricing and value-glamour, may be different but can be captured with the same variable, namely, the $E / P$ ratio. It is worth noting that there is no consensus in finance literature about the causes of the value-glamour anomaly itself. These remaining open questions are the limitations of this study that are left for future research.

\section{References}

Ball, R. 1992. The earnings-price Anomaly. Journal of Accounting and Economics 15 (2/3): 319-346.

Beaver, W. 2002. Perspectives on recent capital market research. The Accounting Review 77(2): 453-474

Capaul, C., and I. Rowley, and W. F. Sharpe. 1993. International value and growth stock returns. Financial Analysts Journal (Jan/Feb).

Chan, K. C. 1988. On the contrarian investment strategy. Journal of Business 61(2): 147-164.

Chilsom, J. R. 1991. Quantitative applications for research analysts. Investing Worldwide II, Management Association for Investment and Research.

Collins, D., and P. Hribar. 2000. Earning-based and accrual-based anomalies: One effect of two? Journal of Accounting and Economics 18:3-42. 
Conrad, J., and G. Kaul. 1988. Time-variation in expected return. Journal of Business 61 (4): 409-425.

De Bondt, W.F.M and R. Thaler. 1985. Does the Stock Market Overreact? Journal of Finance 40(3): 793-805.

De Bondt, W. F. M., and R. Thaler. 1987. Further evidence on investor overreaction and stock market seasonality. Journal of Finance 42 (3): 557-581.

Dechow, P. 1994. Accounting earnings and cash flows as measures of firm performance: The role of accounting accruals. Journal of Accounting and Economics 18: 3-42.

Fama, E. F. 1970. Efficient capital market: A review of theory and empirical work. Journal of Finance 25: 383-417.

Fama. E. F, and J. MacBeth. 1973. Risk, return, and equilibrium: Empirical tests. Journal of Political Economy 81 (3): 607-636.

Fama. E, and K. French. 1992. The cross-section of expected stock returns. Journal of Finance 47 (2): 427466.

Fama. E. F., and K. French. 1993. Common risk factors in the returns on stocks and bonds. Journal of Financial Economics 33 (1): 3-56.

Fama, E. F. 1998. Market efficiency, long-term retruns, and behavioral finance. Journal of Financial Economics 49: 203-306.

Fama. E. F, and K. French. 1988a. Permanent and temporary components of stock prices. Journal of Political Economy 96 (2): 246-273.

Fama. E. F., and K. French. 1988b. Dividend yields and expected stock returns. Journal of Financial Economics: 3-25.

Fama. E. F., and K. French. 1996. Multifactor explanations of asset pricing anomalies. Journal of Finance 51 (1): 55-84.

Foster, G., J. Olsen, and T. Shelvin. 1984. Earnings releases, anomalies, and the behavior of security returns. The Accounting Review 59 (4): 574-603.

Fuller, R. J., L. C. Hubert, and M. J. Levinson. 1993. Returns to E/P strategies; higgledy piggledy growth; analysts forecast errors; and omitted risk factors. Journal of Portfolio Management 19: 12-24.

Graham, B., and D. Dodd. 1934. Security Analysis. New York, NY: McGraw Hill.

Jaffe, J., D. B. Keim, and R. Westerfield. 1989. Earning Yield Market Values and Stock Returns. Journal of Finance XLIV (1): 135-148.

Jensen, M. C. 1978. Some anomalous evidence regarding market efficiency. Journal of Financial Economics 6: 95-102.

Keppler, A. M. 1991. The importance of dividend yields in country selection. Journal of Portfolio Management (Winter).

Kothari, S. P., J. S. Sabino, and T. Zach. 1999. Implications of data restrictions on performance measurement and tests of rational pricing. Unpublished Working Paper. Cambridge, MA: Massachusetts Institute of Technology.

Kupiec, P. H. 1993. Do stock prices exhibit excess volatility, frequently deviate from fundamental values, and generally behave inefficiently? Financial Market, Institution, and Instruments 2 (1). New York University Salomon Center. 
Lakonishok, J., A. Shleiver, and R. Vishny. 1994. Contrarian investment, extrapolation, and risk. Journal of Finance 49 (5): 1541-1578.

La Porta, J. Lakonishok, A. Shleifer, and R. Vishny. 1997. Good news for value stocks: Further evidence on market efficiency. Journal of Finance 52 (2): 859-874.

McNichols, M., 2000. Research design issues in earnings management studies. Journal of Accounting and Public Policy 19 (4-5): 313-345.

Pincus, M., S. Rajgopal, and M. Venkatachalam. 2005. The accrual anomaly: International evidence. Unpublished Working Paper. The University of Iowa: Tippie College of Business.

Sanders, L. A. 1995. The advantage to value investing: Value and growth styles in equity Investing. Association for Investment Management and Research Conference Proceedings.

Sartono, A. 2002. Overreaction of the Indonesian capital market: Is market rational? Bunga Rampai Kenangan. BPFE. Yogyakarta.

Sloan, R. 1996. Do stocks prices fully reflect information in accruals and cash flows about future earnings? The Accounting Review 71 (3): 289-315..

Susiyanto F. M. 2002. Market's overreaction in the Indonesian stock market. Bunga Rampai Kenangan. BPFE. Yogyakarta.

Wahyuningsih, T. 2000. Pengujian short-run market overreaction di Bursa Efek Jakarta. Unpublished Thesis. Universitas Gadjah Mada: Program Msi, Yogyakarta.

Warninda, and M. Asri. 1998. Dapatkah strategi contrarian diterapkan di pasar modal Indonesia? Pengujian anomali winner-looser di BEJ. Jurnal Ekonomi dan Bisnis Indonesia 13 (2).

Xie, H. 2001. The mispricing of abnormal accruals. The Accounting Review 76 (3): 357-373. 